336 (1943)

32）市川, 土橋, 印刷局研究所時報, 7, 295（昭 30）

33）市川，本誌，6，444 (1957)

34) E. Fisher, "Colloid Dispersions", John Wiley \& Sons, Inc., New York, p. 287-8 (1950)

36) U.S. $2,180,721 ; 2,301,142 ; 2,301,143$

37) A. Voet, 印刷局研究所時報附録特別講演集, 21 集 (1955)

38) R. Bowles, J. Oil \& Colour Chemists' Assoc., 33, $72(1950)$

39）市川，伊藤，印刷局研究所報告，No. 1 (1957)

40) J. Fetsko, W. Walker, A. Zettlemoyer, Am. Ink Maker, 33, (12) 38 (1955)

41) R. Buchdahl, J. Thimm, J. Applied Phys., 16,
344 (1945)

42) A. Zettlemoyer, C. Dickert, W. Walker, R. Meyers, Am. Ink Maker, 32, (4) 42 (1954)

43) Wochenblatt für Papierfabrikation, 81, (22) 819 (1954)

44) E. Barber, J. Davis, TAPPI, 34, (10) 433 (1954)

45) J. Albrecht, K. Schirmer, International Bulletin, 73, (1) 47 (1956)

46) 市川, 伊藤, 印刷局研究所時報, 8, 267 (昭 31)

47) O. Anderson, B. Steenberg, Svensk Papper stidn., 53, 1 (1950)

48) A. Voet, (27) の著書の p. 153

49) A. Voet, Am. Ink Maker, 27, (2) 29 (1949)

\title{
マーガリン，ショートニングのレオロジー的考察
}

榎本 朗*

\section{On the Rheological Aspect of Margarine and Shortening}

Akira Enomoto, Jun KawaI and Shinji Mitsunaga

\section{ま元がき}

高分子化学の進歩飞伴いレオロジ一研究の動向は近年 きわめて活発であり，従来官能的主観的取扱いから余り 飛躍しなかった食用油脂加工分野にもレオロジカルな物 性研究が第生えつつある現状である。この分野に特いて 流動学的諸問題は多くめるが，製造面に和いてはグリセ リド組成, 油脂の水添, 凝固法の問題が重要であり, 固 液比, 結晶の物理性, 温度処理, ウォーキングなどが粘 弾性を決める支配的要素となる。一方製品と括いては伸 展性, クリーミング性, ショートニング性, 乳化分散性 なぞが消費者の評価の重要な役割を果している。

戦後食生活の転換と量的消費によって急速に伸展して きたマーガリン，ショートニング類はとの歴史よび本質 的性格のため価值判定の手段，基準は官能検査を主体と せざるを得なからた。しかしこのような検査研究に客観 性を持たせる目的で今日まで種々の手段が試みられ，主 観的な物性判定に頼っていた粘弾性の表現も分子構造解 明のための物理的基礎研究の進歩とともに遂次体系づけ られていく方向にあり，その結果は大いに期待できるる のと考光られる

マーガリン，ショートニグに関した粘弾性研究は発展 の過程にあるとはい光の報文はきわめて少なく，本稿

* 日本油脂株式会社王子工場（東京都北区豊島四丁 目)

Vihon Oils \& Fats Co., Ltd., Ōji Factory
も招のずから概念的とならざるを得ないが， Bailey そ の他 ${ }^{1)}$,2),31,4),5) とよって紹介された報文を中心にまず油 脂の組織的性質と流動学的性質の関連性につき記し, 最 後に製品の粘弾性測定について概説することにする。

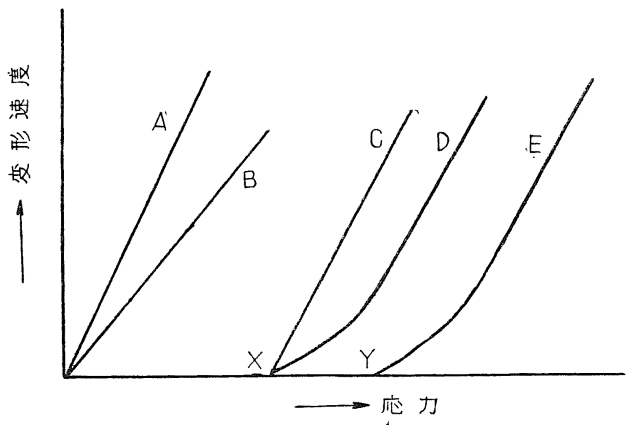

図-1 流 動 曲線

\section{可塑性油脂の構。造}

可塑性物質と粘性物質との根本的相違を流動曲線図-1 そよって説明すると, 直線 $\mathrm{A}, \mathrm{B}$ はニュートン流動を示 す粘性物質でこのもののチョウ度は単に粘度として表わ され，直線の傾斜は粘度によって変り， BはAょり粘性

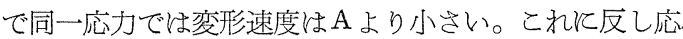
力がある値を越したときと流動が起る，すなわち可塑性 流動を示す理想的可塑性物質は直線 C (ビンガム曲線)を 描き，個々の結晶粒子はある程度弾性を持つのでX点ま 
での力を吸収して永久変形を起さない。マーガリン，シ ョートニングのような可塑性物質ねDのよろな曲線を描

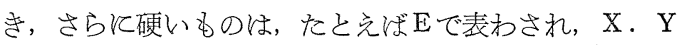
点がいわゆる降伏点である。これら物質のチョウ度は降 伏価と, 直線の傾斜放らり表わされる粘度との二つの成 分から形成され，粘度も降伏価同様部分的飞結晶の大き さ，固液の比，温度などに関連したものでめる。

また一般とレオロジカルな物質はたいていチキソトロ ピー現象を示すが，このような物質に和いてはウォーキ ングを与えるとチョウ度は減少し，そのまま静置すると 徐々にもとのチョウ度に戾る挙動が認められる。チキソ トロピー効果についてはまだ完全な説はないが，固体粒 子のウォーキング間の一時的な配向，または相互凝集力 の一部を一時的に消失するためと考兄られている。

マーガリン, ショートニングのチョウ度, 可塑性, 伸 展性などの物理性は, その本質执よび応用面に和ける重 要な挙動の一つであって，これらの特性は最終製品をつ くるためと関連した種々の团子のため複雑である。

Bailey は可塑的であるためとは,

i）二相からなり，一相は固体，他相は液体であるこ と。

ii）固相は内部凝集力によって互いと十分保持できる ほど細かく，から固体粒子の大きさは各粒子間の間

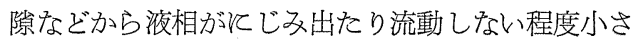
いこと。

iii）液相, 固相間には適当な比率が保持されること などが必要であると述べている。

マーガリンは油脂の連続相に水滴が分散した状態飞和 いてショートニングと異なるが, 油脂相とついてはショ 一トニング同椂上記条件があてはまる。固相の率は温度 変化とともに連続的に変るものであるからチョウ度に及 ぼす温度効果の大半は固液の関係比飞起因し, 他の䂛も な因子は液相の粘度に及ぼす温度効果である。チョウ度 に及に゙す他の因子として, 固体粒子の大きさ, 形状, van der Waals の力の度合などがあげられるが，以下との主 要因子机て列挙寸る。

\section{チョウ度に及ぼす因子}

\section{1) 固体の割合}

油脂のチョウ度に最も直接に影響を与えるものは固相 の含量であり, 固体の含量は温度によって変化し, また 液相の粘度も温度とよって変るゆ光粘度もまたチョウ度 飞影響を及煌す。

ショートニング製造当っては, 可塑性範囲の広いグ リセりドからなる油脂を選び，マーガリンの場合はその 本質からみて明らかなよう飞軟化融解がシャープで可塑 性範囲の狭い油脂を選ぶのが常道であり, チョウ度の度 合は消費者の好み, 使用場所, 季節によって調節するの
が通例である。したがって可塑性油脂として最良の製品 をうるためとは透温範囲と扔ける固液の比々つての知 識を持つととがきわめて重要である。

S $\phi 1$ toft 飞上机ば油脂中の固体含量とカタサ(firmness）祘上粘度との関係は 図-2，3のようとなる。

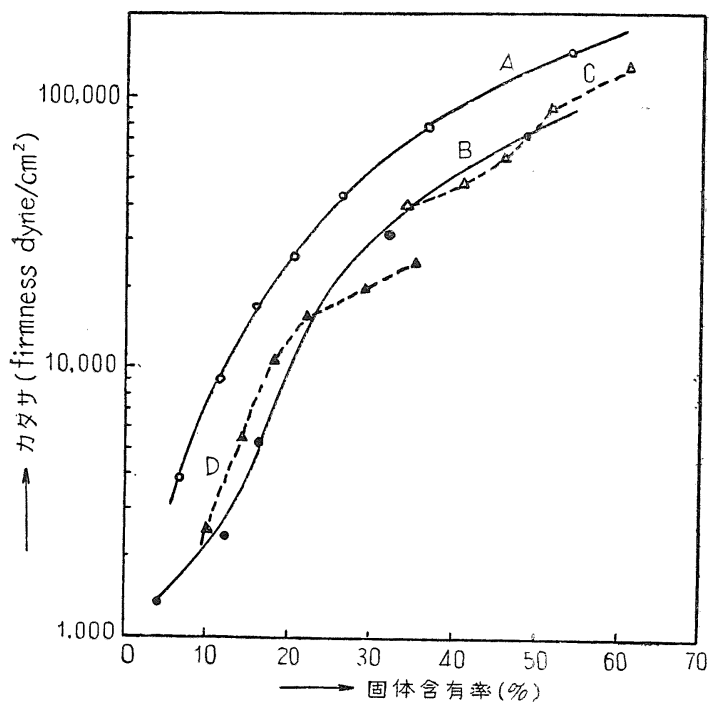

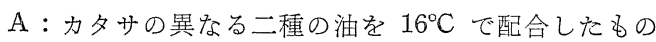
B : " " $28^{\circ} \mathrm{C}$

$\mathrm{C}$; カタサのあまり異ならない二種の油を $16^{\circ} \mathrm{C} /$

D :

-2 カタサと固体含量の関係

いずれるカタサは固体含量と比例して増加しているが, 実験的に求めた粘度，固体含量間の関係は不定であるか ら，カタサの評価より粘度の評価の方がむずかしい。 Bailey, Singleton の提出した各種油脂酒ついての固体 含量対 こクロペネの関係図（図-4）学久てもわかると招 り, 低含量部分では微量の固体含量変化はチョウ度に大 きな影響を与える。

\section{2）結晶の物理性}

図-2，図-3，より結晶はチョウ度飞同一の効果を持た ぬこと、特よびへテ口的な油脂とホモ的な油脂とを比べ ると一定の割合の結晶でほ前者の方がカタサ, 粘度とる に大きいことがわかる。同じような效果は 図-4 の曲線 と和いても観察される。すなわち少量の高度水添油を含 む油脂 D以選択水添綿実油を主体とした B より同一チョ ウ度では固体含量が少ない。いいか党れば同一固体含量 飞轻いては, 前者の方がかたい。これ怡高融点グリセり ドからなる結晶は低融点グリセりドの結晶より硬化能力 が大きく, 剛性も強いためと考党られる。

可塑性油脂のチョウ度は結晶の大きさとよって著しい 影響を受ける。すなわち結晶粒子の平均形状が減少すれ ばかたくなりまた増大するほど柔かくなる。これは他 


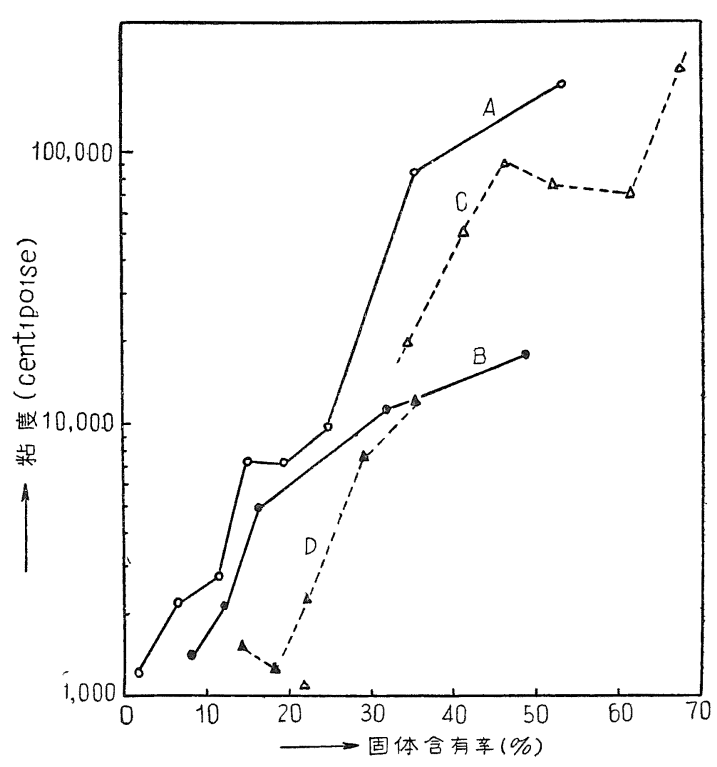

A B C D 国-2 河し

図-3 粘度と固体含量の関係

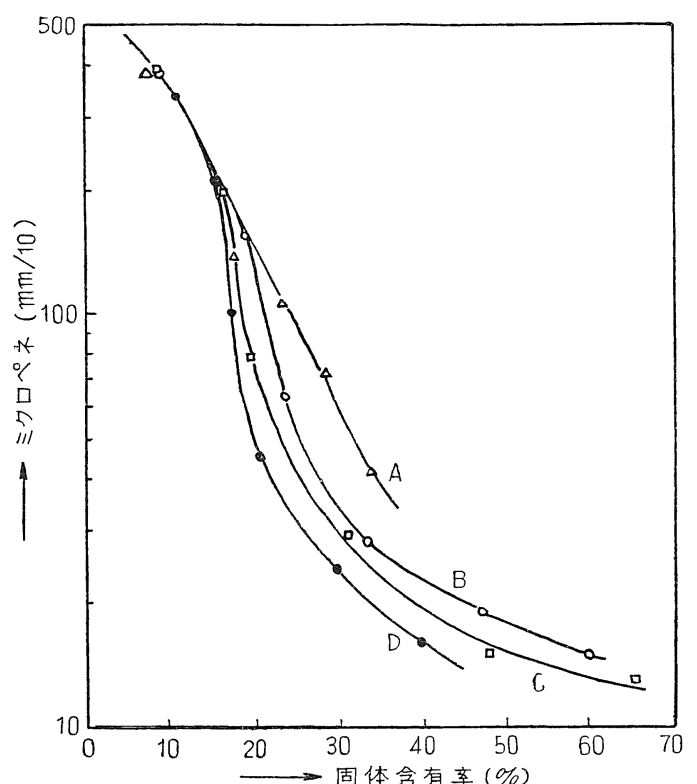
A 豚脂
B 部分水厓綿実伷
C オレオオイル
D.クリスコ (P\&G 社ショートニング)

図-4 ミクロペ市と固体含量の関係

の因子か一定てめれは, 形状か小さくなれは粒子か接触 する機会か増し，また流動させる場合打ち勝つたけの摩 擦の増加のためかたくなるからてある。ゆえに徐冷固化 したものは急冷固化したるのより柔かくなる。図-4 可塑性油脂のチョウ度は固体脂含量たけてなく, 結晶粒
子の大きさ，形状，剛性，扣よひ分散また集合の度合 なとマ影響されることも示している。

トリグリセリドの物理的挙動ほ構成脂肪酸の種類和よ ひグリセロール基への結合位置なとれよって多種多様て ありグリセリト組成は他の要因同様チョウ度に及ほすす 影響は大きい。最近可塑性油脂のチョウ度を改良する目 的でグリセリトのインターエステル交換, 再配列により グリセリト組成をへテロ的に変換させる試みか行なわ れ，工業的《字実施されている( $), 7), 8$ 。

固体状態にあるトリグリセリト分子の空間配列は純奘 試料のX線回析法により種々研究されているか子，近似的 にその配列の型を図示すると図-5 のと招り交互に重な り合った tuningfork(音父) の形をとって配列するとさ れている。

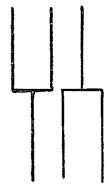

(A)

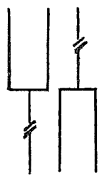

(B)

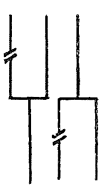

(C)

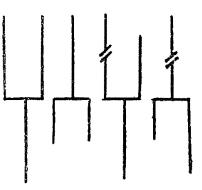

(D)
凶-5トリクリセリトの分子配列

安定型結晶についてのみ述べると，(A) 弾一飽和卜 リグリセリト分子の配列であるか，このような分子は凝 固すると parred unit の層を作り，よく揃った安定結 晶格子登㔙成する。この構造ては各公子は隣接分子と最 も接近した形をとるため van der Waals の力は強力な 結合効果を発揮する。したかって分子を離すには多量の エネルギーを要し, 結晶は高融点特よひ高い融解熱を有 することとなる。(B), (C) は不飽和酸, たとえはオレイ ン酸を持つトリグリセリド $(\alpha, \beta)$ の一例てあるか，才 レイン酸鎖は固体状態ては二重結合の存在によって線状 とならす直鎖の場合死と密な充テンてはならないため van der Waals の力はいくらか低下し，乙たかって分 子を離す余りエネルギーを必要としないゆ学結晶の 融点, 融解熱は低くなる。この現象は(B)より (C) の埸 合の方か著しく現われる。各種トリグリセリトの混合物 はたとえは（D）のような型をとる。このようなへテロ 的分子ては千密充テンはとれすさらに不揄いな結晶格子 を形成する。Hoerr ${ }^{9}$ は豚脂結晶か割飞均一なチ密充テ ン構造を示し自由表面エネルギーか比較的低いためと大 きく成長することをインターラードと比較して説明して いる。一般と結晶の大きさは他の因子が等しけれは，そ の自由表面エネルギーと関係し，完全結晶てはエネルギ 一零で, この值は分子充テンの不完全度に比例して増加 するといわれる。

\section{3）液相の粘度}

同一固体含量飞稀いてカタサ招よひ粘度は $28^{\circ} \mathrm{C} よ り$ 


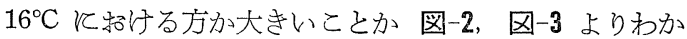
る。これは液相の粘度かカタサ，粘度に影響することを 表わし， S $\phi$ ltoft は実験結果から温度によるカタサの偏 差の $30 \%$ 牤よひチョウ度の偏差の $50 \%$ は固液比の変 化よりむしろ液相の粘度の変化と起因していると結論し ている。

少量の高度水添伷と液体油からなるショートニンク, たとえば 10\%の高度水添綿実油と $90 \%$ の綿実油の混 合油の膨張変化はきわめて少ないか，チョウ度に括いて は相当変化かあることか知られている。これは腋相の粘 度変化に起因するからてある。またこのような型の昆合 物に物いては水添度の余り異ならないホモ的な二種の混 合油より一定のカタサ (firmness) てほ粘度は低い。（図 -6 参照)

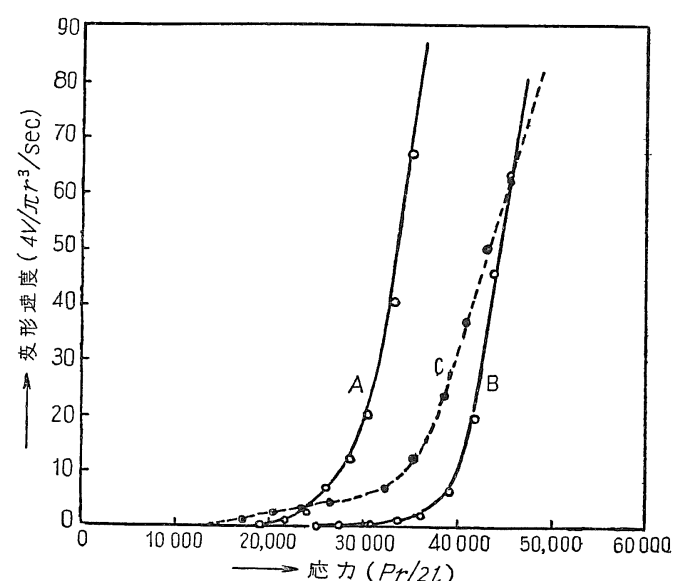

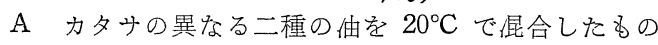
$\mathrm{B}$ " " $16^{\circ} \mathrm{C}$ " $\mathrm{C}$ カタサのあまり異ならない二種の伷を $24^{\circ} \mathrm{C}$ ”

园-6 可塑性伷脂の流動曲線

(一定カタサ飞物ける粘度の相違)

\section{4) 過冷却}

マーカリン, ショートニングの可塑化に重要かつ複雑 な要因としてクリセリトの過冷却性かある。過冷却の度 合扎よひ過冷却製品か結晶平衡に達するのに許さるへき 温度は製品の可塑性飞直接関係している。トリグリセり 卜は他の高分子化合物同様に著しく過冷却されやすいる のてあり, 製造直後のマーカリン, ショートニングにお いては夜状油脂か過冷却状態て存在し, 内部の状態ほ熱 力学的不平衡状態にあるため結晶化とともに骨格状構造 を生成し製品のカタサか增加してゆく。高融点グリセり ト叔よひ低融点グリセリトまたは夜体油の配合てショー トニンクを低温て製造, 貯蔵 $\left(0 \sim 5^{\circ} \mathrm{C}\right)$ したものはかた くならす異常に柔かさ定保つか, 結晶成長加早い平衡温 度に貯蔵すれはかたくなって可塑性か広くなる。これは ポリモリフィスムにより低融点の不安定型結晶力生成さ れ，低温の粘度の低下のため結晶生長か遅く過冷却の持
続性か効き，貯蔵温度をあけれは一部融解画絬昆により 高融点安定結晶加生成されて広範囲の温度変化侕光う る可塑性を生久出すからてある。

トリグリセリトか一種以上の結晶型を持つとと，すな わちポリモリフィスム現象を表わすことはよく知られて いるか, ポリモリフィスムはカカオ脂, オレオオイル, 単一型グリセりトを主体とした高度水添油和よひこのよ うな油と收体油との屁合油など特いて最る多くみら れ, 豚脂, 部分水添油なと融解温度範囲の忩いクリセリ トからなる油脂に和いては余り認められない。普通, 融 解膨張変化の大きい（融解のシャープなるの）配合油は 膨張変化の少ないものより過激な冷却を必要とし, あら い結晶体を生成しやすい油脂には特に必要てある。

一般飞過冷却の持続性はグリセりトの飽和度か増すに 従い，また飽和グリセリトか倱合型から単一型に近付く そ従い大きくなり，固花平衡に達しにくくなる。すなわ ら混合型飽和グリセリトては急速に不安定型より安定型 へ転移するといわれている。

\section{5）機裓的ウォーキング}

過冷却された可塑性油脂の凝固を静止状態て行なえは， 油脂は異常にかたくなりその可塑性範囲は悪く製品飞李 た組織のなめらかさて欠き色子均一てなくなる。機械的 ウォーキングのない急速凝固は結晶を一つにし，不連続 結晶状態になっている同一固体含量のものよりはるか、 強力な骨格状構造か生成される。ウォーキングこの結 晶構造をこわし再配向させるととによって斦体部分に招 ける結晶の流動性をよくするように，すなわち剛性か可 塑性に変るように組織を再配列させる。この変化はグリ セリト組成とか気温応してウォーキング度合を変觉る わけてあるか，結晶の大きさか適当て固体部か 35〜40\% ぐらいの温度て行なえは最上の結果か得られるとされて いる。も乙温度か余り低いと粘性か心かるため液体部は 結晶の再配列のための自由行動を少なくしてしまう。

ゆ光飞最大可塑性範囲を持つ結晶構造は急冷と凝国期 間中に適度の機械的ウォーキングを行なうことによって 確立される。

完全に結晶化し十分ウォーキングを受けたものてもチ キソトロピー現象を表わすことは Mulder ${ }^{10)}$ か報告して いる。

ショートニンク，マーガリンと適用するウォーキンク の度合はつきの点て異なる。すおらマーカリンの場合，

a）包装 あまり柔らか過さると包装不能になるの て，最小限度のウォーキンク下て結晶平 衡に達するようにする。

b）分散度 掖相か極度に細かく分散すると製品か粘 くなり塩味か劣る。

c）結晶の大きさ 結晶を俎大にした方か口溶けかよ く低缊に叔忷る伸展性もまさる。 
過冷却和よひ過冷却油脂飞適用するウォーキングの度 合かショートニングの性質にいか影響するかの一例 を, Joyner ${ }^{11)}$ は可塑性流動を起させるに 要するミキシ

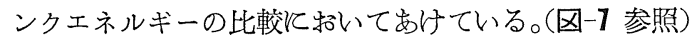

過冷却かショートニンクのカタサ招よひクリーミンク （抱気）性飞及注す影響の一例を表-1, 目-8 亿あける。 すなわち結晶構造の相違とより, 低温部のカタサ括よひ クリーミンク性の持続はB の方か良好てある。

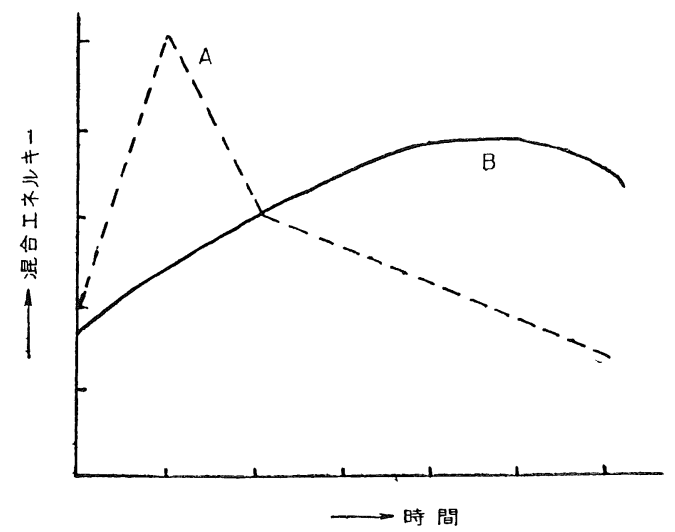

A 流量 $10,000 \mathrm{lb} / \mathrm{hr}$, 冷却温度 $20^{\circ} \mathrm{C}$

B 流量 $8,000 \mathrm{lb} / \mathrm{hr}$, 冷却温度 $18^{\circ} \mathrm{C}$

凶-7 温度, ウォーキンクのミキシンクエネルキー そ対する影響

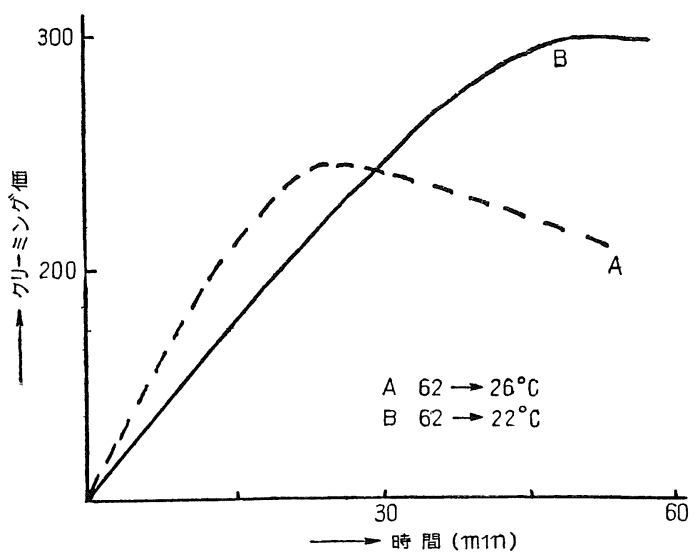

凶-8 冷却温度とクリーミンク価

表-1

\begin{tabular}{c|c|c|c} 
& \multicolumn{3}{c}{ カタサ $(\mathrm{g})$} \\
\hline 製造 冷却条件 & $225^{\circ} \mathrm{C}$ & $10^{\circ} \mathrm{C}$ & $235^{\circ} \mathrm{C}$ \\
\hline (A) $62^{\circ} \mathrm{C} \rightarrow 26^{\circ} \mathrm{C}$ & 9 & 97 & 11 \\
\hline (B) $62^{\circ} \mathrm{C} \rightarrow 22^{\circ} \mathrm{C}$ & 7 & 74 & 8 \\
\hline
\end{tabular}

則定值は各温度に二日間放置後測定したもの。

\section{6) 温度処理}

㣙脂の受ける温度履歴もまたチョウ度に大きい影響を
与光るものてあり, 特飞原料㣙脂の决まっているハター 製造と和いては, 温度処理とウォーキンクのみかチョウ 度を块定する因子と考光ても差支光ないくいてある。 マーカリリンの可塑性改良には乳化中の温度管理と過冷却 とよって結晶核生成を調整する方法か有効である Andersen は述へている。適度な固腋比を持つるのてる 極端とウォーキングを強くし，冷却温度を低くすると， 微細な結晶か過剩と生成されてかたくなりすきる。この 傾向を少なくするには，乳化中の結晶核生成管理を行な わなけれはならない。結晶核力生成されると温度低下に よる夜体部の粘度増加のため結晶の動きか抑制され，か くはんを激しくしなけれは核の周囲に大きな結晶か生成 されやすくなる。一度核か生成されると核は温度変化中 結晶化のための中心として持続し，融点より数度温度か 上って子顕微鏡的大きさを保持し，再ひ冷却したときと より大きな結晶炕発展する中心となるといわれる。

ホテーターてショートニンクを製造する場合る，急冷 前と予泠して結晶核がなるたけたくさんてきるような方 法を採っている。

ショートニンクは一般に製造直後 $25 \sim 30^{\circ} \mathrm{C} て 24 \sim 48$ hr 熟成工程を行なろのか普通てある。熟成は製品の可 塑性をよくするためと行なうのてあるか，熟成中には低 融点クリセリトか部分的飞融解し, 貯蔵中の気温低下飞 よる緩慢な冷却によって大小の結晶を持った適度な構造 そ変えるのて，熟成により製品は愠度変化にあってる使

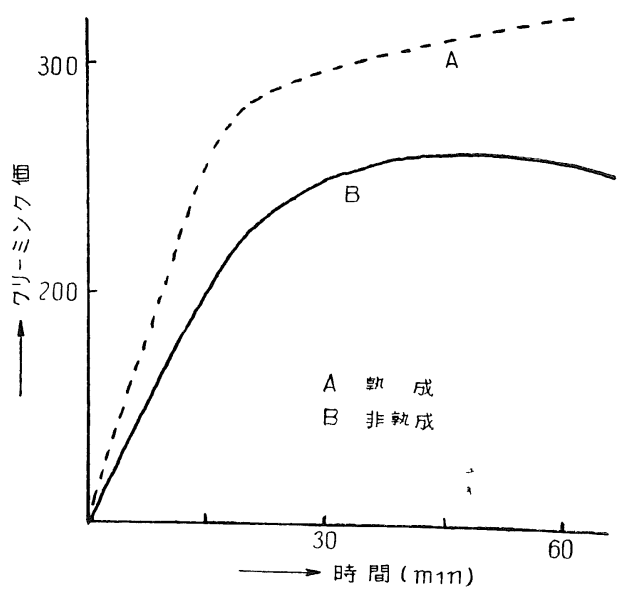

凶-9 熟成とクリーミンク価

用時の温度ては最も望ましい可塑性を取りもどすよう調 節される。組織的飞もより均一て機械的飞強い結晶粒子 となり,クリーミンク性は熟成しないものよりよくなる。

\section{(表-2, 囚-9 参照)}

熟成によるチョウ度変化は緩慢な再冷却々よる粗大結 晶の生成と, 低温度飞搁ける固体脂含量の低下のためと 考方られているか ${ }^{12)}$, 部分的融解, 再結晶後の検鏡ては 結晶の変化は認められす長時間の熟成ては長針状結晶と 
表-2

\begin{tabular}{l|c|c|c} 
& \multicolumn{3}{c}{ カタサ $(\mathrm{g})$} \\
\hline & $225^{\circ} \mathrm{C}$ & $13^{\circ} \mathrm{C}$ & $235^{\circ} \mathrm{C}$ \\
\hline 熟成品 $\mathrm{A}$ & 5 & 48 & 45 \\
\hline 非熟成品 $\mathrm{B}$ & 10 & 53 & 9 \\
\hline
\end{tabular}

$\mathrm{AB}$ とも製造条件同じ, 熟成は $29^{\circ} \mathrm{C}, 24 \mathrm{hr}$

変りかえってかたくなることもある⿸广。

マーカリンの場合にも熟成の効果は認められるか, 熟 成により油脂組織の軟化した細胞間質中に水㒀を合一ษ しめてエマルションを部分的にアンハランスにしたり, 表面の水分か䔲発したりするのて熟成は実際的てなく不 可能てある。

\section{粘弾性測定法}

可塑的特性と弾性的特性を有するマーカリン, ショー トニング類の粘弹性を測定する客観的方法は多くの研究 者によって試多られてきているか, これらは総合された すへての硬度特性を個々に異なる特殊な条件下て求めて いるのて, より直接的て実際的な方法はまた得られてい ない。現在われわれか採用している測定法はチョウ度の 差異をたた数值的に表示するための罗当性かあるのみ て, 試料そのものの粘弾性のすへてを表現しろる方法て はない。

粘弾性測定法は大別して単一応力反よる静的測定と周 期的応力による動的測定の二種に分けられる。高分子材 料その他の最近の進歩は，低周波領域加可聴周佊まる いは超音波領域林動的測定法の駆使によって促進 されたといっても過言てはない。これと反しマ一カリ ン, ショートニンク類の粘弾性測定法は, その大半か静 的方法てあり, 動的測定の適用はこの分野の今後に残さ れた一課題といえる。

可塑性の表示法上して多少の理論性を持つものは結局 流動変化の决定てあるか, 流動変化を図式的に求めるも のに毛細管プラストメーター法かある。これは Bingham か見出した可塑性物質についての式

$$
\begin{aligned}
& \mu(F-f)=\frac{d v}{d r} \quad F \text { セン断応力 } \\
& f \text { 単位面積当りの正切応力 } \\
& v \text { 流速 } \\
& r \text { 二層間の距離 }
\end{aligned}
$$

から出発して, Buckingham か発展させた式

$$
\begin{array}{rlrl}
\frac{V}{t} & =\frac{\pi R^{4} \mu}{8 l}\left(P-\frac{4}{3} p+\frac{p^{4}}{3 P^{3}}\right)+\frac{\pi R^{3} \varepsilon P}{2 \eta l} \\
V / t & \text { 流量/sec } & P & \text { 圧力 } \\
R & \text { 毛細管半径 } & p & \text { 降伏值の圧 } \\
\varepsilon & \text { 潤馉層の厚さ } & &
\end{array}
$$

を基礎として

$$
\begin{aligned}
& A=\frac{\eta \pi R^{4} \mu+4 \pi R^{3} \varepsilon}{8 l \eta} \\
& B=\frac{\pi R^{4} \mu p^{4}}{24 l,}, \quad C=\frac{4 p \pi R^{4} \mu}{24 l}
\end{aligned}
$$

と置きかえて得た式

$$
\frac{V}{t}=A P+\frac{B}{P^{3}}-C,
$$

飞実測值 $\left(P_{1}, \frac{V_{1}}{t_{1}}\right)$

$\left(P_{n}, \frac{V_{n}}{t_{n}}\right)$ をプロノトした曲線上の 3 点を上式に代入 乙て得た三元連立方程式をとき， $B, C$ を求め, さら反 次式尤り $p, f, \mu$ を求める。

$$
p=\sqrt[3]{\frac{4 B}{C}}, f=\frac{R}{2 l} \sqrt[3]{\frac{4 B}{C}}, \quad \mu=\frac{3 C}{\pi R^{3} f}
$$

毛細管法の一例の構造を 凶-10 と示す。

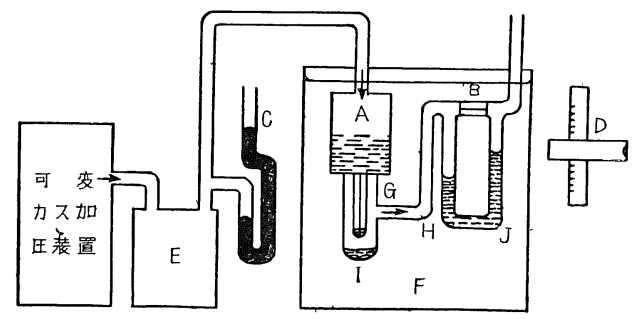
$\mathrm{A}$ 試料容器, $\mathrm{B}$ カス流量計, $\mathrm{C}$ 圧力計
$\mathrm{D}$ 読み取り器, $\mathrm{E}$ 空気加圧タンク $\mathrm{F}$ 恒温ソウ
$\mathrm{G}$ 毛細管, J 圧力計

凶-10 毛細管プラストメーター

可塑性試料力毛細管 $\mathrm{G}$ を通ってI 亿流出すると, 流出 量と等容の空気か Bを通って押出される。Dを用いて J の圧力減少を読み $V / t$ を知る。流出させた圧力をCて読 む。このようとして塑粘性, 降伏価を求めることかてき るか, 計算かかなり面倒てあること, 測定值と計算值の 一致か少ないことなとのほか、，塑性曲線か直線になら ないという本質的な欠陷かある。

毛細管法を油脂飞適用したものに S $\phi$ ltoft の方法 ${ }^{14)}$ か ある。かれは長さ $100 \mathrm{~mm}$, 直径 $29 \mathrm{~mm}$ の毛細管に試 料を入れ, 定温, 定圧(空気圧)下て押出される油の量を 測定して流動変化を実験的に誘導した。毛細管の半径 $r$, 長さ $l$, 壁飞扣けるヒス之力 $S$, 変形速度 $D$, 単位時間 の流出量を $V$, 管の一端に加えた圧力を $P$ とすれは二 ュートン流動ては

$$
S=\operatorname{Pr} / 2 l, D=4 V / \pi r^{3}
$$

ヒンカム流動ては

$$
S=\frac{P-(4 p / 3)+p^{4} / 3 P^{3}}{2 l,}, D=4 V / \pi r^{3}, p \text { 降伏 }
$$

点て表わされる。

凶-1 に挌けるDのようと $P$ が $p(X)$ 以下の值ては 流動㤝起らす， $P$ か $p$ を越觉るとますいわゆるすへり (slip) か認められ,つきに試料の粘度に等しい傾斜を持 
つ流動を示すと至る。S $\phi$ ltoft は cc/mun または secて 表わした $4 V / \pi r^{3}$ 亿対して dyne $/ \mathrm{cm}^{2}$ て表わした $P r / 2 l$ をプロノトして実験的に粘度, 降伏価を求め, $3 / 4 \times p$ の 值を伷脂のカタサ “firmness”とした。この方法は可塑 性を数值的に表示し得ない欠点はあるか, 求められた流 動曲線は則定器の大きさと無関係て, 流動変化を図式的 にありのまま表示し,変形の実相を指示する利点かある。

原料招よひ中間製品の測定に応用される簡易法に Feuge $^{15)}$ のミクロ針入度法かあるか，最終工程に捈け る冷却, ウォーキンク, 熟成なとの条件缸品のチョウ 度に大きな影響を与えるのて，この方法て测ったチョウ 度は製品のチョウ度と必すしも一致しない久点かある。 固体脂含量測定には膨張計法 ${ }^{11)}$ かむり，水添の管理，配 合原料の管理なとに利用されている。最終製品のチョウ 度側定にはグリースの ASTM 針入度計, Kruisheer ${ }^{16)}$ の硬度計の利用から発展して $\mathrm{Clardy}^{17)}$ とょって改良さ れたコンシストメーターか広く用いられている。このメ ーターは 図-11 のよろとスプリングを内蔵した筒とケ ーシ括よひプランシャ一からなり, プランシャ一の先の シリンターの内壁は, 試料か開口を貫通するとき変形が 起るように円スイ形になっている。

チョウ度を測定するには試料の平らな面に $30 \mathrm{sec}$ 当 り $11 / 2$ nch の貫通速度をるってプランシャーを押圧

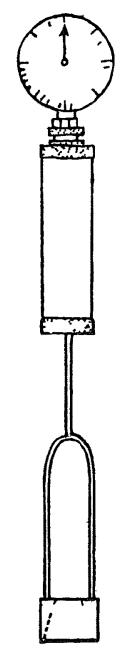
したときの最高压力を読み取ってコンシ ステンシーとする。この方法の利点は, 容器に入ったるのの測定に便利なことて あるか, 得られる硬度指数は一種の降伏 価を表わすとはい光，乙か乙とれは貫通 速度 $30 \mathrm{sec}$ 間飞 $11 / 2 \mathrm{nch}$ という側定 条件下て求めたものてあるから, シリン ダーの大きさ, 貫通速度か変化すれは異 なった側定值か得られる。

最近, 動的側定法の一つの試みとして ブラベンターのファリノグラフを利用し たレオメーターか紹介されている18)。フ アリノグラフは小麦粉の物理性判定に使 用されているメーターて，定速回転する 倱和機の腕飞刘するパン生地の抵抗变化 凶-11 コンシ を自動記録し，その自記クララよりカタ ストメーター サ, 安定度などパン生地の流動性か判定 てきるものてある。Loska の考案したレオメーターは ASTM グリースウォーカーとファリノクラフを組み合 わせたものて試料をクリースウォーカーと充テンし，ウ ォーカー自体恒温ソウにつけて則定する。上下運動によ って武料に応力を与える多孔板付きピストンのストロー ク数を横軸に, 各ストローク数に执いてファリノクラフ か示す最大メーターグラムトルク(ストローク抵抗)にス
トローク数を掛けた数值を縦軸炕とって得られる曲線か ら, 最初の抵抗力誩よ粘性変化のスロープか求められる。 (図-12 参照)。かれはこの二つからチョウ度と変形に対 する安定度加かるとし， $222^{\circ} \mathrm{C}, 30^{\circ} \mathrm{C}$ て則定した試 料の傾斜の正切值によって可塑範井を表わしている。

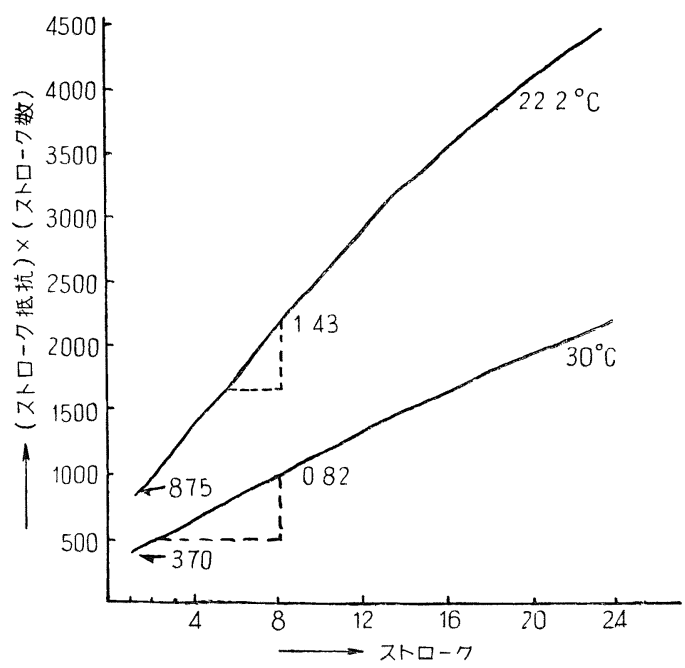

目-12 裂型豚脂の変形曲線

最後飞, Moh1 ${ }^{19)}$ か提唱したハタ一の粘弾性測定法を 参若に付記する。かれは $20^{\circ} \mathrm{C}$ に持ける切断硬度拓よひ 固有断面屈曲度 (形状硬度), $15^{\mathrm{C}} \mathrm{C}$ 飞和ける切断硬度, 加圧断面屈曲度和よひ伸展度なとの測定か有効てあると 述へている。

切断硬度は $1 \mathrm{~g}$ の下台を有する台ハカリの上飞, 一辺 $25 \mathrm{~cm}$ の正六面体の試料を扣き, $01 \mathrm{~mm} / \mathrm{sec}$ の速度て 直径 $03 \mathrm{~mm}$ の斜金により切断したときの台ハカリに 及注す力 $(g)$ て読夕取られる。固有断面屈曲度は試料の 自重による変形を測定するものて, $2 \times 2 \times 10 \mathrm{~cm}$ の試料 を $8 \mathrm{~cm}$ の間嘹にある 2 枚の刃に乗せられた上板の上に 括き, $6 \mathrm{hr}$ 後の試料のギョウ(撓)曲を $\mathrm{mm}$ て表わした ものてある。加圧断面屈曲度は $2 \times 2 \times 10 \mathrm{~cm}$ の試料を八 タ一棒の自由間隙か $6 \mathrm{~cm}$ となるように 2 枚の刃の上に 扮かれた坐板の上に拉き，これに下端か门 $55 \mathrm{~mm}$, 長 さ $68 \mathrm{~mm}$ V作られた加圧用鉄帯を $01 \mathrm{~cm} / \mathrm{sec}$ の定速 度て加圧し, 台八カリの目盛涀われる最高の力（この 值を越えるとハタ一棒を割れるかまたは裂け始める）を 測定する。伸展度は特製箱汇試料を入れこれに $2 \mathrm{~mm} の$ 厚さの金属板を押込んて上昇した厚さ $2 \mathrm{~mm}$ のハタ一層 を $1 \mathrm{~cm} / \mathrm{sec}$ の定速度て刃を綱によりケン (率)引し， ハカリと網巻き器についたゼンマイハカリとの間に現わ れた抵抗の最大值を側定する。Mohr અ各種のハターに ついて試験した結果, $20^{\circ} \mathrm{C}$ て切断硬度か $15 \mathrm{~g}$ 以上, 形 状硬度か $07 \mathrm{~mm}$ 以上, $15^{\circ} \mathrm{C}$ ては伸展度方最高 $1 \mathrm{~kg}$, 切断硬度か最高 $100 \mathrm{~g}$ のハターか完壁てあるとみなして いる。 


\section{あとがき}

周知に属する事項を列記したきらいがあるが，以上油 脂の粘弾性に影響を与える主要因子特よび測定法につい て大要を述べた。

欧米に比べ原料特よび消費面に特いて事情を異にする わが国では，まだ解決されていない問題が数多くあり， まず諸現象に対応した基礎的本質を体系的に解明してゆ かなければならない現状とある。しかし今後, 食用油脂 加工分野では風味改良の研究と相末って, 流動学的諸問 題の究明は品質の改良または新分野開拓の面からいっ て，より一層の努力と期待が望末れる次第である。

(昭和 33 年 9 月 30 日受理)

\section{文献}

1) A.E. Bailey, "Melting and Solidification" (1950)

2) A.E. Bailey, "Industrial Oil and Fat Products" (1951)

3) A.J.C. Andersen, "Margarine", London (1954)

4) G.W. Scott Blair, 新食品学 (1953)
5) H. Green, "Industrial Rheology and Rheological Structures", New York (1949)

6) F.E. Luddy et al., J. Am. Oil Chemists' Soc., 32, 522 (1955)

7) H.K. Hawley et al., ibid., 33, 29 (1956)

8) E.W. Eckey, Ind. Eng. Chem., 40, 1183 (1948)

9) C.W. Hoerr, J. Am. Oil Chemists' Soc., 32, 41 (1955)

10) H. Mulder, "International Dairy Congr.," 181 (1949)

11) N.T. Joyner, J. Am. Oil Chemists' Soc., 30, 526 (1953)

12) Fulton et al., ibid., 31, 98 (1954)

13) N.N. Hellman et al., ibid., 32, 110 (1955)

14) S\$ltoft, Pro. Intern. Rheol. Congr., II, 273 (1948), III, 72 (1949)

15) R.O. Feuge, A.E. Bailey, Oil \& Soap, 21, 78 (1944)

16) C.I. Kruisheer et al., Chem. Week., 35, 719 (1938)

17) L. Clardy et al., J. Am. Oil Chemists' Soc., 29, (1952)

18) S.J. Loska, J. Am. Oil Chemists' Soc., 34, 495 (1957)

19) W. Mohr, Fett u. Seifen, 52, 342 (1950)

\section{訂正および補足}

Vol.7, No.2 総説「天然ステリンについて」の訂正挌よび補足

$$
\text { 松本 }
$$

オリザノール稀よびシクロユーカレノールについて娛 って記載し，またとの後の報告も発表されたのでつぎの と特り訂正する。

p. 67 左欄 28 行目から 30 行目まで

オリザノールは金子, 土屋飞よって発見され ${ }^{58)}$, 生化 学的活性が認められ, 数種のトリテルペンアルコールの フェルラ酸エステルとされた ノ一ルを分別し, そのうち2種はシクロアルテノール

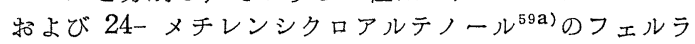
酸エステルとした。シクロアルテノールはまたナタネ油 飞も存在し ${ }^{60)}$ ，オリステリン…….......

p. 67 右欄の表

シクロユーカレノールの項は削除する。

p. 68 右欄 13 行目から 21 行目まで

シクロラウデノールが知られている。これは $C_{31}$ で $24 \mathrm{~b}$-メチルの配置とされた。

上記のシクロユーカレノールはとの後, $4 \beta$ - ジチ ル -24-メチレンシクロアルテノールとされ72a), ステリ ン核にさらにメチル基が 2 つ置換している。

ジメチル誘導体としてはまた 4,4'- ジメチル -7-コ レステノールがネズミフン（霬）から分離されだ5)。

さらにモノメチル誘導体としてシトラジエノール $(4 \alpha$. メチル -7,24(29)- スチグマスタジエノール) るオレン 淁皮などから分離された

このよ5な物質は $\mathrm{C}_{30}$ のトリメチルステリンから通常 のステリンへ移る生化学的中間物質とも考学られ, 興味 深いものであろう。したがってステリン核のメチル誘導 体としてはつぎのと特りに分類できる。

$$
\int \begin{aligned}
& \text { ステリン } \\
& \text { メテルステリン }
\end{aligned}
$$

太郎

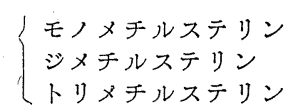

その他 $\mathrm{C}_{27^{-}}$ステリンとして 7- コプロステノール (Colemann \& Baumann), $\Delta^{5.7 .22}$ コレスタトリエノー ル（高木，外山）が分離された。また天然のステリンが フェルラ酸エステルとしても存在することが明らかにさ れた（田村，松本ら）。

その他の訂正（一印插入「」印削除）

p. 62 右欄 5 行目 ラノステリンなどは $460 \mathrm{~m} \mu$ 物よ p. $\frac{\text { び }}{63}$ 左欄 25 行目 これねよる $\mathrm{V}_{\mathrm{C}=\mathrm{C}} 1670 \mathrm{~cm}^{-1}$ 以外 9

”右闌 26 行目 知られているが, $970 \mathrm{~cm}^{-1}$ 飞強

$\frac{2}{11}$

”右欄表アプトスタノール 24 a M 20 a

p. 64 右欄 29 行目 アプトステリンは 「還元生成物 が」

p. 68 右欄 20 行目 吉田らは $\beta$-オリステノール $\left(\mathrm{C}_{30} \Delta^{25}\right)$

追加文献

58 a) 土屋, 加藤, 遠藤, 東工試報告, 51 , 359 (1956)

59 a) G. Ohta, M. Shimizu, Chem. \& Pharm. Bull., 6, 325 (1958)

72 a) J.S.G. Cox, F.E. King, T.J. King, Proc. Chem. Soc. 1957, 290

75) W.W. Wells, D.N. Neiderhiser, J. Am. Chem. Soc., 79, 6569 (1957).

76) Y. Mazur, A. Weizmann, F. Sondheimer, ibid., 80, 1007 (1958); A. Weizmann, Y. Mazur, J. Org. Chem., 23, 832 (1958) 